\title{
Frequency of Lentz Bodies Inclusion in Erythrocytes of Whole Blood and Expanded Buffy Coat Smears
}

\author{
Monica Alejandra Camargo Castillo, Bruno Albuquerque de Almeida, \\ Felipe Yuji Okano, Angelica Menin \& Stella de Feria Valle.
}

\begin{abstract}
Background: Canine distemper has been classified as highly contagious for most of domestic and wild carnivores, and the infection can be fatal. Canine distemper inclusion bodies, also denominated Lenz inclusion bodies, are large aggregates of viral nucleocapsid particles that can be form in red blood cells (RBCs), white blood cells (WBCs) and epithelial cells in many tissues during the acute phase of infection. Their presence in blood is transient and rarely encountered in light microscopy but are pathognomonic when identified in blood smears. The objective of this study was to investigate the frequency of distemper inclusions in erythrocytes according to the fraction of the sample used for blood smears.

Materials, Methods \& Results: The study was conducted with routine blood sample provided by the Veterinary Laboratory of Clinical Analysis from the Veterinary Teaching Hospital of Universidade Federal do Rio Grande do Sul. The EDTA- $\mathrm{K}_{2}$ blood sample of a 40 days old male dog, mixed breed, no immunization records, presenting diarrhea, hyporexia, myoclonus and pustules in the abdomen, was selected. In a routine peripheral blood smear examination, several distemper inclusions were observed in the erythrocytes. From this sample, ten smears were performed using a whole blood (WB) and top erythrocyte fraction combined with buffy coat, denominated of expanded buffy coat (EBC). The EBC fraction was obtained after centrifugation of EDTA whole blood in microhematocrit tubes at $9600 \mathrm{~g}$ for $5 \mathrm{~min}$ to obtained the packed cell volume (PCV) and buffy coat. After centrifugation, the blood cells are separated into three layers based on density: platelets (adjacent to supernatant), WBCs, and RBCs in the bottom. The PCV was measured and the microhematocrit tube was ruptured $2 \%$ below the interface between leukocytes and plasma, deposited into a plastic microtubes, homogenized and used for blood smear preparation. All smears were stained with Diff-Quick Stain. The frequency of observation of RBCs with distemper inclusions bodies was performed under optical microscopy, in the immersion objective (100x), accounting for complete fields up to a minimum of $1000 \mathrm{RBCs}$, and compared between WB and EBC. In comparison between blood smears obtained from WB and EBC, a highly significant difference $(P=0.0004)$ was observed in the frequency distribution of distemper inclusion. The median of frequency of RBCs with distemper inclusions in a WB smears was 12.68/1000 RBCs (10.1 - 16.1/1000 RBCs), with a coefficient of variation (CV) of 12\%. Median of frequency of distemper inclusions from EBC smears was 54.23/1000 RBCs (45-77.9/1000 RBCs), CV of 18\% were observed. The median frequency of inclusions found in EBC smears was 4.27 times higher than the WB smears.

Discussion: Buffy coat smear providing a concentrated preparation of nucleated cells and this procedure is useful to looking for low-incidence infectious organisms or other hematologic alterations. The upper fraction of the RBC column, below the buffy coat, is composed of young RBCs. Selection of these portion, and their possible formed in the bone marrow viral replication phase, could justified the increase in the frequency of RBCs containing viral inclusions in EBC, which would also increase the sensitivity of the technique. EBC was homogenized previously to make the smears, certifying the adequate cell distribution in the slide surface without interfere with the frequency of distemper inclusion in RBCs observation. These results were confirmed with the coefficients of variation. In conclusion, distemper inclusions bodies in RBCs from $\mathrm{EBC}$ is a recommended diagnosis method in patients suspected of canine Distemper infection. The observation being more frequent in the EBC in comparison with WB, commonly used in veterinary hematology.
\end{abstract}

Keywords: distemper inclusion, centrifugation, canine, blood packed cells.

$$
\text { DOI: } 10.22456 / 1679-9216.97846
$$




\section{INTRODUCTION}

Canine distemper virus (CDV) is a Morbillivirus, from Paramyxoviridae family [15] and has been classified as highly contagious for the most of domestic or wild carnivores, and can be a fatal infection [7]. The definitive and early diagnosis of Distemper infection can support the establishment of appropriate therapy and definition of prognosis.

Currently, distemper diagnosis is based in viral inclusions observation in cytological samples (blood or tissue), direct staining or fluorescent antibodies, histopathological evaluation, virus isolation or RNA detection [12]. Distemper inclusion bodies are formed during CDV viral replication in blood and endothelial cells, they are transient and rarely found in light microscopy in a peripheral blood [18]. In optic microscopy, these structures are intracytoplasmic and eosinophilic, formed from the excess of unused proteins [4]. As these remnants of viral replication are only found in cases of distemper virus infection, their finding in a blood smear is pathognomonic.

In hematology, as component of complete blood count (CBC), light microscopy is widely used in veterinary medicine, making methods that increase its sensitivity extremely useful to laboratorial routine. Previous studies report that buffy coat smear analyzes increase the probability of viral inclusions findings [9] and the rate of diagnosis (57\%), when compared to the WB (43\%) [13]. The rate of diagnosis of distemper viral inclusions are related to their presence in RBCs, since they were no observed in WBC [13].

There are no investigations about the frequency of distemper viral inclusion in WB and buffy coat. The objective of this study was to investigate the distemper inclusions frequency in RBCs, according to the portion used to make blood smears, considering WB and EBC.

\section{MATERIALS AND METHODS}

\section{Samples}

The study was conducted with a routine sample for propose diagnosis, from the Veterinary Clinics Laboratory (LACVET) at the Veterinary Teaching Hospital (HCV) of the Federal University of Rio Grande do Sul. The canine sample was selected when several distemper inclusions were observed in the routine blood smear evaluation (Figure 1). The sample was from a 40 days old male dog, mixed breed, no immunization records, presenting diarrhea, hyporexia, myoclonus and eruptions in the abdomen, which are suggestive of Distemper Infection. The blood sampling was performed by a veterinary clinician. A $2 \mathrm{~mL}$ sample was obtained from jugular venipuncture using EDTA-K $\mathrm{K}_{2}$ as anticoagulant and, immediately, submitted to an automated blood cells count (ProCyte Dx) ${ }^{1}$.

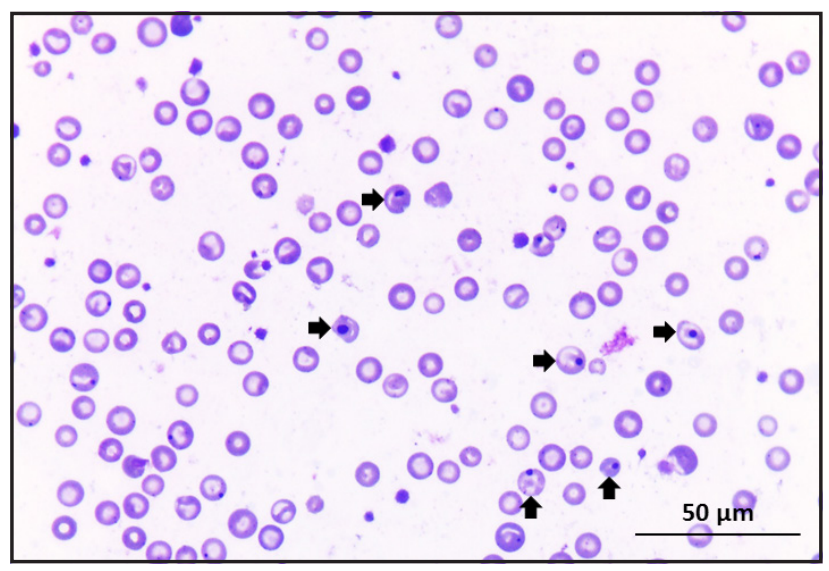

Figure 1. Canine distemper inclusion bodies in RBCs (arrows) [Diff Quick Stain; 100x].

Smears

Ten smears were performed using WB and ten smears were performed with the top erythrocyte fraction combined with buffy coat (is a concentrated blood cells obtained from centrifugation in capillary tubes), denominated EBC. The EBC fraction was obtained after centrifugation from the microhematocrit tubes for $5 \mathrm{~min}$ at $9600 \mathrm{~g}$ (Heraeus Pico 17 Microcentrifuge) $)^{2}$. After that, the PCV was measured and the microhematocrit tube was ruptured $2 \%$ below the interface between buffy coat and packed RBCs. The percentage considered was arbitrarily defined and the EBC fraction was deposited into microtubes, homogenized and posterior blood smear preparations were made. All smears were stained with Diff-Quick Stain (Instant Prov) $)^{3}$ more specific to distemper viral inclusion visualization.

The frequency of distemper viral inclusions was performed under optical microscopy, in the immersion oil objective (100x), accounting for complete fields up to a minimum of $1000 \mathrm{RBCs}$ in each smear. Twenty smears were considered and WBC with distemper viral inclusions were not considered.

\section{Statistical analysis}

The number of RBCs containing distemper viral inclusions (per $1000 \mathrm{RBCs}$ ) was submitted to 
the normality test (Kolmogorov-Smirnov), and subsequently to the Mann-Whitney U test for nonparametric data. In addition to descriptive variables (median, minimum and maximum value), the coefficient of variation $(\mathrm{CV})$ was calculated for 10 blood smears performed on different smears, which is obtained by the formula $\mathrm{CV}=$ standard deviation/mean. The level of significance was $P<0.05$, and tests were performed using IBM SPSS Statistics software, version 22.0 (IBM Corp. Armonk, 2013).

\section{RESULTS}

In comparison between blood smears obtained from WB and EBC, a highly significant difference $(P=$ 0.0004 ) was observed in the frequency of the distemper viral inclusion distribution. The median of frequency of RBCs with distemper inclusions from the WB smears was 12.68/1000 RBCs (10.1-16.1/1000 RBCs), with a $\mathrm{CV}$ of $12 \%$. Median of frequency of distemper inclusions from EBC smears was 54.23/1000 RBCs (45-77.9/1000 RBCs), CV of $18 \%$ were observed. The median of frequency of inclusions found in EBC smears was 4.27 times higher than that WB smears.

\section{DISCUSSION}

This is the first study to emphasize that the using of the EBC smears obtained from expanded buffy coat increases the Distemper viral inclusions frequency of observation in RBCs, using the light microscopy. The increasing of RBCs with inclusions in EBC fraction smears can supports the higher diagnostic rate the sensibility of exam. Surprisingly, the distemper viral inclusions in RBCs could be more difficult to find since the prevalence is considered lower in RBCs than in WBCs population in a stained blood smear [9]. Although buffy coat smear is more often performed with concentrate of nucleated cells, rarely it is made without a small portion of RBCs.

In the laboratorial routine, the packed cells from peripheral blood is obtained by centrifugation of anticoagulant blood sample. After centrifugation, the blood cells are separated into three layers based on density: platelets (juxtaposed to supernatant), mixed of all WBCs, and RBCs in the bottom [17]. In this gradient, erythrocytes are the densest cells while platelets are the least dense. Some intrinsic and extrinsic factors can modify the density of RBCs. Plasmodium spp. infected RBCs are less dense than normal, are positioned imme- diately above to the RBC column [3] when blood cells are packed. Considering the characteristic of inclusion, was hypothesized that the same effect can occur with the distemper inclusion-containing RBCs, which can become less dense and be concentrated immediately above to the WBC column in a packed cell.

As described, the upper fraction of the RBC column, below the WBC packed cells is composed of young RBCs [14]. Using EBC as a smear sample, the microhematocrit tube rupture was performed below the interface between RBC and WBCs. The selection of young RBCs in the top of RBC column, possibly formed in the bone marrow during viral replication phase, may be a justification for the increase the frequency of RBCs containing viral inclusions, which would also increase the sensitivity of the technique. This finding corroborates with a previous study, which claims that inclusions are even more frequently found in polychromatophilic RBCs [9].

To certify that cell distribution and the observed portion of the smear did not interfere with the frequency of distemper viral inclusion in RBCs, the EBC sample was previously homogenized before performing the smears. The used methodology created a uniform and representative leukocyte layer in all the slides, which can be observed in the results found for the CVs. The presence of statistical differences in the $\mathrm{CV}$ of both techniques should be explored through a comparison using multiple samples.

Numerous studies have suggested that the presence of distemper inclusions in peripheral blood is a confirmatory evidence in dogs with suspected distemper $[6,11,13,16]$. Previous studies report this finding as uncommon in a blood smear [1,2]. It is possible to state that the blood fraction after centrifugation, used to make the blood smear, is associated with the percentage of distemper viral inclusions found in RBCs in the viremic phase. Further studies are suggesting to investigate the sensitivity and specificity of using EBC as a sample to investigate viral inclusion, comparing WB and more sensitive agent detection techniques (e.g. polymerase chain reaction).

The limitation of this study was due to the sample number. The sample has a high proportion of RBCs containing inclusions, which allowed an adequate frequency comparison using $1000 \mathrm{RBCs}$ as a population. However, establishing frequencies and comparing them can be difficult when samples 
contain rare viral inclusions observed in the blood smear. In addition, due to sample size, the CV was not compared, and the reproducibility of different samples, with larger or smaller proportions of inclusions, are not performed.

\section{CONCLUSION}

In conclusion, distemper viral inclusions in RBCs, a pathognomonic diagnosis findings in patients suspected of canine Distemper, are more frequent in the expanded buffy coat in comparison with whole blood.

\author{
MANUFACTURERS \\ ${ }^{1}$ Idexx Laboratories. Westbrook, ME, USA. \\ ${ }^{2}$ Thermo Fisher Scientific GmbH. Dreieich, Germany. \\ ${ }^{3}$ Newprov Produtos para Laboratório. Pinhais, PR, Brazil.
}

Declaration of interest. The authors report no conflicts of interest. The authors alone are responsible for the content and writing paper.

\section{REFERENCES}

1 Alleman A.R., Christopher M.M., Steiner D.A. \& Homer B.L. 1992. Identification of intracytoplasmic inclusion bodies in mononuclear cells from the cerebrospinal fluid of a dog with canine distemper. Veterinary Pathology. 29(1): 84-85.

2 Batista V., Moura M. \& Reis R. 2000. Ocorrência de corpúsculos de Sinegaglia-Lentz em esfregaços sangüíneos de 70 cães com suspeita clínica de cinomose. Revista Brasileira de Ciência Veterinária. 7: 115.

3 Cabezos J. \& Bada J.L. 1993. The diagnosis of malaria by the thick film and the QBC: a comparative study of both techniques. Medicina Clínica. 101: 91-94.

4 Carlton W.W. \& Mcgavin M.D. 1998. Thomsons's Special Veterinary Pathology. 2.ed. Porto Alegre: Artmed, 672p.

5 Castilho J.G., Brandão P.E., Carnieli Jr. P., Oliveira R.N., Macedo C.I., Peixoto Z.M.P., Carrieri M.L. \& Kotait I. 2007. Molecular analysis of the $\mathrm{N}$ gene of canine distemper virus in dogs in Brazil. Arquivo Brasileiro de Medicina Veterinária e Zootecnia. 59: 654-659.

6 da Silva G.A., Araújo E.K.D., Leite A.G.P.M., Cardoso J.F.S., Oliveira W.A., Santos A.S., Prado A.C. 2017. Parâmetros hematológicos de cães apresentando corpúsculos de Lentz em esfregaço sanguíneo. PUBVET. 11: 947-1073.

7 Deem S.L., Spelman L.H., Yates R.A. \& Montali R.J. 2000. Canine distemper in terrestrial carnivores: a review. Journal of Zoo and Wildlife Medicine. 31(4): 441-451.

8 Green R.G. \& Evans C.A. 1939. A comparative study of distemper inclusions. American Journal of Epidemiology. 29(2): 73-87.

9 Greene C.E. \& Appel M. 2012. Canine distemper. In: Greene C.E. (Ed). Infectious Diseases of the Dog and Cat. 4th edn. Amsterdam: Elsevier, pp.25-42.

10 Harder T.C. \& Osterhaus A.D. 1997. Canine distemper virus - a morbillivirus in search of new hosts? Trends in Microbiology. 5(3): 120-124.

11 Headley S.A. \& Graca D.L. 2000. Cinomose canina: achados epidemiológicos de 250 casos. Brazilian Journal of Veterinary Research and Animal Science. 37(2): 136-140.

12 Loots A.K., Mitchell E., Dalton D.L., Kotzé A. \& Venter E.H. 2017. Advances in canine distemper virus pathogenesis research: a wildlife perspective. Journal of General Virology. 98(3): 311-321.

13 Schweigert A. 2008. Frequência de corpúsculos de inclusão de Lentz em células sanguíneas e oculares de cães suspeitos de cinomose atendidos no Hospital Veterinário da Faculdade Integrado de Campo Mourão-PR. Campo Digital. 1(2): 90-92.

14 Sutton D.W., Chen P.C. \& Schmid-Schönbein G.W. 1998. Cell separation in the buffy coat. Biorheology. 25(4): 663-673

15 van Regenmortel M.H.V., Fauquet C.M., Bishop D.H.L., Carstens E.B., Estes M.K., Lemon S.M., Maniloff J., Mayo M.A., McGeoch D.J., Pringle C.R. \& Wickner R.B. 2000. Virus taxonomy. Seventh report of the International Committee on Taxonomy of Viruses. San Diego: Academic Press, pp.1162.

16 Vicente A.F., Abreu A.P.M. \& Passos A.A.M.S. 2010. Perfil hematológico em cães infectados naturalmente por cinomose com presença de corpúsculo de Sinegaglia Lentz, em Vassouras-RJ. Revista de Saúde. 1(1): 49-54.

17 Yabuki A., Sawa M., Chang H.S. \& Yamato O. 2015. A practical technique for electron microscopy of buffy coats in dogs and cats. Anatomia Histologia Embryologia. 44(4): 317-320.

18 Watson A.D.J. \& Wright R.G. 1974. The ultrastructure of inclusions in blood cells of dogs with distemper. Journal of Comparative Pathology. 84: 417-427. 